\title{
SOCIAL SECURITY PRIVATIZATION REFORM AND LABOR MARKETS: THE CASE OF CHILE
}

\author{
Sebastian Edwards \\ Alejandra Cox Edwards \\ Working Paper 8924 \\ http://www.nber.org/papers/w8924
NATIONAL BUREAU OF ECONOMIC RESEARCH
1050 Massachusetts Avenue
Cambridge, MA 02138 \\ May 2002
}

We are indebted to Manuelita Ureta for helpful discussions, and to Alejandro Jara and Rajesh Chakrabarti for assistance. The views expressed herein are those of the authors and not necessarily those of the National Bureau of Economic Research.

(C) 2002 by Sebastian Edwards and Alejandra Cox Edwards. All rights reserved. Short sections of text, not to exceed two paragraphs, may be quoted without explicit permission provided that full credit, including () notice, is given to the source. 
Social Security Privatization Reform and Labor Markets: The Case of Chile Sebastian Edwards and Alejandra Cox Edwards

NBER Working Paper No. 8924

May 2002

JEL No. H55, J3, P5

\begin{abstract}
We analyze the way in which social security privatization reform affects labor market outcomes. We develop a model of the labor market where we assume that, as is the case in most emerging markets, a formal and an informal sectors coexist side by side. According to our model, a social security reform that reduces the implicit tax on labor in the formal sector, will result in an increase in the wage rate in the informal sector and will have an undetermined effect on aggregate unemployment. Results from simulation exercises suggest that in the case of Chile the reforms resulted in an increase in informal sector wages of approximately $2.0 \%$. These results also suggest that the reforms made a positive, but small, contribution to the reduction of Chile's aggregate of unemployment.
\end{abstract}

Sebastian Edwards

University of California, Los Angeles

Anderson Graduate School of Business

110 Westwood Plaza, Suite C508

Box 951481

Los Angeles, CA 90095-1481

and NBER

sebastian.edwards@anderson.ucla.edu
Alejandra Cox Edwards

California State University, Long Beach 


\section{Introduction}

In recent years policy makers, politicians and academics have become deeply concerned about the future of social security. The specter of a massive insolvency crisis has generated, throughout the world, a frantic search for a solution to what the World Bank has called the "old age crisis." Conferences have been organized, wise-men groups have been assembled, and blueprints for reform have been discussed. Throughout this process, and in an effort to learn from lessons of experience, many analysts have focused on Chile's pioneering social security reform. In 1980 Chile replaced an insolvent government-run social security system, by a privately managed system based on individual retirement accounts. Almost twenty years after the launching of this privatization effort, the Chilean experience has become a required case study for anyone interested in reforming social security. ${ }^{1}$ Most analyses of Chile's experience have concentrated on three aspects of this privatization program: (1) Its effect on the fiscal accounts, including its effect on public sector's contingent liabilities. (2) The effects of the new system on old-age pensions, including a comparison of replacement rates under the old a new regime. And (3) the effects of the reform on aggregate national savings. ${ }^{2}$

Surprisingly, very few studies of the Chilean episode have dealt with the overall labor market implications of the social security reforms. This, however, is not unique of the Chilean case. In fact, while a number of studies for a variety of countries have analyzed the way in which social security systems affect labor market incentives for older individuals, very few authors have analyzed formally the way in which a major social security reform affects overall labor market outcomes. ${ }^{3}$ And yet, it may be argued that a reform that (in principle) changes the rate of payroll taxes, and affects the relationship 
between social security contributions and future earnings will have substantial effects on the aggregate and (sectoral) demand and supply for labor. This would be clearly the case if contributions to the pay-as-you go system are considered (at least in part) a tax, and contributions to individual retirement accounts are seen largely as deferred compensation. ${ }^{4}$

The privatization of social security - either partially or fully - is likely to have a particularly significant effect on overall labor markets outcomes in emerging economies, including in former socialist nations. Most emerging countries are characterized by segmented labor markets, where a modern and an informal labor market coexist. Under these circumstances, only those employed in the "modern" segment will be covered by labor market regulations, including social security. Those employed in the so-called informal sector work without formal contracts, generally do not pay taxes, are not affected by minimum wages laws, and are excluded from the formal safety net.

The purpose of this paper is to analyze the way in which a social security reform of the Chilean-type affects labor market outcomes in an economy characterized by a segmented labor market. Our main interest is to evaluate the way in which Chile's social security reform affected the country's level of employment, its rate of unemployment and wages. In order to do this we develop a model of the labor market in an emerging economy, and we simulate it using parameter values for Chile. We also use micro survey data to investigate some key features, such as coverage, of Chile's privatized social security system.

The paper is organized as follows: Section I is the introduction. In Section II we provide a brief evaluation of Chile's social security reform. Section III deals with the 
effects of social security reform on wages, income distribution, employment and unemployment. The section begins with a general discussion of Chile's labor market reforms. We next develop a model of a segmented labor market to analyze the way in which policies aimed at reducing the tax component of social security contribution affect the key labor market variables. In section IV we use micro survey data to obtain an estimate of the "tax component" of social security contributions under Chile's privately managed social security system. ${ }^{5}$ We then use, in Section V, the results from this empirical analysis to simulate our model, and compute the effects of Chile's social security reform on employment, unemployment and wages. The results from our simulation exercise suggest that the effect of the reform on Chile's aggregate employment was rather modest. The results also suggest that the reforms resulted in a small increase in average wages. Finally, in section VI we provide some concluding remarks.

\section{The Privatization of Chile's Social Security System}

In late 1980 Chile's military regime privatized the country's traditional pay-asyou-go social security system. ${ }^{6}$ Twenty years after Chile's social security reform, most observers agree that Chile's program was a true pioneer, and that there is much to learn

from it. In this section we provide a brief discussion of the main aspects of the reform.. ${ }^{7}$

\section{II.1 The Old Pay-as-you-go System}

Chile's original social security system was designed in the 1920s as a collective capitalization fund. Accumulated funds, however, were poorly managed, and benefits -- especially for the better to do -- escalated quickly. For all practical purposes, 
and in spite of the original intentions of its founders, by the 1970s the system had become an insolvent pay-as-you-go regime, characterized by very high contribution rates. In 1973, for example, total contributions to the retirement plan -- by employers and employees -- averaged 26 percent of wages. Once contributions to the national health system were included, total contributions exceeded, for some workers, 50 percent of wages. What made things worse was that there was almost no connection between retirement contributions and (perceived) benefits. Contributions were largely seen as taxes, while benefits received from the social security system were seen as entitlements. ${ }^{8}$

While in 1955 there were 12 active contributors per retiree, by 1979 there were only 2.5. As a result of this, and of a highly inefficient management, the Chilean system became increasingly unfunded. By the early 1970s the system as a whole was already running a dramatic deficit. The gap between revenues and outlays -- administrative costs plus pensions -- was made up by the public sector. By 1971 the central government's contributions to the retirement system amounted to almost $3 \%$ of GDP, and the present valued of the system's contingent liabilities exceeded 100\% of GDP.

\section{II.2 The Privatization of Social Security in Chile}

In 1980 the military privatized the social security system. The core of Chile's new privately managed system are individual retirement accounts managed by private companies known as "Administradoras de Fondos de Pensiones", AFPs. A key feature of the system is that it is mandatory for individuals working for a formal employee. Participants can freely decide which AFP will manage their retirement funds, and are free to transfer them across the different management firms. Upon reaching the minimum pensionable age, individuals can choose to buy an annuity, or to withdraw their funds 
according to a predetermined (actuarially fair) plan. ${ }^{9}$ The system also has a survivor's term life insurance component, and a disability program funded with an additional insurance premium. In the reformed system, the State continues to play an important role. It regulates and monitors the operation of the management companies, and guarantees a minimum pension ${ }^{10}$. In an effort to increase the attractiveness of the new system, and in order to reduce political opposition, contribution rates under the new system were lowered; as a result, those individuals that joined the new system experienced an average increase of net take-home pay equal to $10 \%{ }^{11}$ It was expected that, given the anticipated higher rates of return on the accumulated funds, the lower contributions would be enough to finance higher replacement rates for pensions.

Contributions to the retirement component of the system are equal to $10 \%$ of income, considerably lower then the $26 \%$ (on average) under the old system. Total contributions for retirement, health and survivorship insurance add up to $20 \%$ of wages, with a cap equivalent to an annual wage rate of US\$40,000 per year. A detailed regulatory framework -- enforced by an institution especially created for this purpose, the Superintendency of AFPs -- regulates investment portfolios, ensures free determination of fees and commissions and free entry into the industry. Until 2000, each AFP could manage only one retirement fund; likewise, each participant could have only one retirement account.

Self employed workers are not required to participate in the system. They have the choice, however, to set voluntary retirement accounts which are (basically) subject to the same regulations as those of formal sector employees. In 1998 the percentage of active contributors - that is those making deposits into their retirement accounts --stood 
at $58 \%$ of total employment, with an additional $4 \%$ of workers still contributing to the old system. This means, then, that in 1998 the total coverage of the Chilean retirement system amounted to $62 \%$ of employment. The $38 \%$ that is not covered by the social security system corresponds, largely, to those that work in the informal sector, or to the self employed (for details on the actual characteristics of those not covered by the new system, see the discussion in section III of this paper). At $62 \%$ of employment, the current coverage of the system is similar to that of the old pay-as-you-go system.

The volume of pension funds privately managed by the AFPs has increased dramatically. Between 1985 and 1997 they increased from 10\% of GDP to almost 45\% of GDP. Furthermore, recent simulations suggest that by year 2010 the accumulated funds will represent $110 \%$ of GDP, and that by 2020 they would have reached $134 \%$ of GDP. ${ }^{12}$ The type of assets the retirement funds can invest in are tightly regulated. During the early years, funds were largely restricted to government securities, bank deposits, investment grade corporate bonds and mortgage bonds. At this time, however, a number of equities, both domestic and foreign, are allowed.

During the early years of the reform the real (inflation adjusted) average rate of return of accumulated funds was very high, averaging during 1982-1995, 12.8 percent per annum. More recently, however, the real rate of return has declined significantly, and has averaged, between September 1994 and August 2000 the (real) rate of return for the system was $4.9 \%$. This rate is rather low, and has raised some people's concerns about the system's ability to deliver pensions with a relatively high replacement rate in the future. 
Existing regulations impose a floor on the return individual AFP pay to their members. In any given year an AFP cannot pay a return lower than 2 percentage points of the system's average. If the actual return of a particular AFP falls below this minimum, the difference has to be made up by using funds from a specially set "reserve fund." The restriction on a minimum rate of return, coupled with the regulations that each AFP cannot have more than one fund, and that individuals cannot distribute their funds across funds, reduced the extent of competition of the system, and resulted in the different AFPs holding extremely similar portfolios. Reforms introduced in 2000, however, have allowed each AFP to have a second fund.

The new system allows men to draw a pension at 65 , and women at 60 , or earlier if they have accumulated enough funds to finance a pension of 70 percent of their (pensionable) salary. When an individual retires he can choose between two systems: (A) he can use the accumulated funds to buy an annuity from an insurance company; or, (B) he can chose to enroll in a "programmed withdrawal" scheme, where the accumulated funs are drawn according to an actuarially determined schedule. By 1997 there were already 250,000 retirees receiving pensions under the new system. Of these, approximately one half had opted for annuities, and one half for programmed withdrawal. Using a sample of 4,064 individuals, it has been estimated that the average replacement rate under the new system had amounted to $78 \%$, significantly higher than under the old pay-as-you-go regime. $^{13}$

The new system also establishes that, for those individuals that qualify, there is a minimum pension guaranteed by the state, which as of December 1998 was equal to $85 \%$ of the minimum wage. From an international comparative perspective, replacement rates 
have been quite high in Chile - indeed higher than under most industrialized countries' systems. ${ }^{14}$

\section{II.3 Transitional Costs and Weaknesses of the New System}

Most proposals to privatize social security, struggle with issues related to the transition. Chile dealt with this problem in a simple, and costly manner. All transitional costs were borne by the government and were paid out of the general budget. Individuals that had been contributing to the old system received government bonds - the so-called "recognition bonds". These bonds yielded per annum $4 \%$ in inflation adjusted terms, an were placed in the each individual retirement account. The value of the bonds received by each person was determined using a formula that took into account their history of contributions to the old system. From a fiscal point of view the transition was rather expensive, representing almost 5\%of GDP in the peak year of 1983. It is estimated that by 2015 these costs would have almost disappeared.

The privatized Chilean system has exhibited two important weaknesses: First, at $62 \%$ of workers, the level of total coverage of the new system is low. This is explained by two basic factors: first, the self-employed - which are not legally required to participate in the system-- have limited incentives to make voluntary contributions. Second, the existence of a government-guaranteed (universal) minimum pension creates a moral hazard situation among low income workers, many of which are self employed.

For these individuals it pays to contribute only sporadically, and only enough as to obtain

the minimum pension once they retire. ${ }^{15}$ Second, the cost of running the private system in terms of fees, commissions and, especially, marketing costs - has been very high, 
tending to exceed, during the last few years, $10 \%$ of contributions. This has resulted in a significant reduction of the net rate of return accrued to participants. ${ }^{16}$

\section{II.4 Chile's Social Security and Labor Market Reforms}

The reform of social security was only one component of a broad effort to transform Chile into a modern market economy. During the second half of the 1970s the military government implemented a number of fundamental reforms, including a major overhaul of the tax system, the opening up of the economy to international competition, the privatization of most state owned enterprises, and the creation of a modern financial market. In the early 1980's the scope of the reforms was broadened to include labor markets and social security.

In 1979, and under considerable international pressure, the military government initiated an effort to reform Chile's labor legislation. The main objectives of these

policies were: (a) To reform job security legislation, by limiting the extent of severance payments. These were reduced form "one month per year of service, with no limit", to “one month per year of service, with a 5 months limit." (b) To reduce unions' power by decentralizing collective bargaining, and eliminating the old "close-shop" practice. And (c), reduce payroll taxes. This last measure was to be achieved, partially, by the social security reform, discussed above. ${ }^{17}$

Between 1985 and 1997, Chile's labor markets performed well. ${ }^{18}$ What makes this experience particularly interesting is that between 1983-85 and 1993-95, Chile went from rates of unemployment usually associated with some European countries, to unemployment rates similar to those traditionally prevailing in the U.S. While during 1983-85 the open rate of unemployment averaged $17.3 \%$, by $1993-95$ it had declined to 
5.8 percent. And all of this while real wages experienced rates of growth in excess of 5\%

per year. ${ }^{19}$ An interesting question is which of the components of the labor-related reforms - the reduced degree of job security, the reformed collective bargaining, or the social security reform -- were more important in helping Chile improve its labor market performance. Although providing a full answer to this question is beyond the scope of this paper, in section III we develop a model that allow us to quantify the effect of the social security reform on some of the key labor market variables. We proceed as follows: we first develop (in Section III) a model of segmented labor market, and investigate the way in which changes in taxes on labor in the "covered or modern" sector impact labor market outcomes. Next, in Section IV, we use micro survey data to analyze the extent to which participants considered the new system as a "deferred compensation" scheme. Finally, in Section V, we calibrate and simulate the model for the case of Chile. Our findings suggest that the social security reform had a modest effect on Chile's labor market performance. This, however, needs not be the case in other countries: the actual impact of a Chile-style social security reform on unemployment, wages and income distribution will depend on the specific values of the relevant parameters.

\section{A Model of Social Security Reform and Labor Markets}

In this section we develop a two-sector model to analyze the effects of a social security reform on employment, unemployment and wages. Labor markets in emerging economies in general - and in Chile, in particular -, have a number of institutional features that set them apart from labor markets in industrial nations. The most important among these features are: 
- In emerging countries labor markets are usually characterized by a rather large "informal" segment. This segment is, de facto, not directly affected by labor market regulations, such as minimum wages, job security legislation or social security. The informal sector coexists with a "modern" sector, where labor market regulations are fully in effect. The fact that in Chile the social security system covers only $62 \%$ of those employed, provides some evidence of the existence of this segmented structure. $^{20}$

- Contributions to social security are often seen as a (partial) tax on labor, rather than as deferred compensation, or an insurance program. At the same time, benefits from these programs are seen by individuals as an entitlement. The percentage of the contribution that is actually considered a pure tax depends on the nature of the social security system and, more specifically, on the perceived connection between contributions and benefits. $^{21}$

Formally, assume that, as is the case in many developing and transitional economies, the labor market is segmented. There is a "modern" or "covered" sector subject to a minimum wage and to social security coverage, and an "informal" or "unprotected" sector with no social security coverage, and competitively determined wages. With other things equal, workers will rather be employed in the "protected" sector. The problem, however, is that there are not enough jobs in that sector; individuals that apply for a job in the modern sector face a probability (p) of obtaining it, and a probability (1-p) of being unemployed. In equilibrium, and under the assumption of risk neutrality, the wage rate obtained in the informal segment is equal to the expected (take home) wage rate in the protected sector. We further assume that every period employment in the modern sector 
turns over fully, so that the probability of getting a job in that sector is equal to the ratio of openings to applicants. ${ }^{22}$

We assume that prior to the reform workers in the protected sector are subject to a payroll tax - whose purpose is to fund the social security system-equal to $T_{1}$. We also assume that there is a disconnect between social security contributions and benefits. More specifically, we assume that social security contributions are considered by individuals to be fully a tax. Notice, however, that the analysis that follows would not be affected by the assumption that only a fraction of the contribution was considered to be a tax. Workers employed in the modern sector receive a "take home" wage rate equal to the minimum wage $\left(\mathrm{W}_{\min }\right)$. The cost of labor to firms operating in this sector is equal to the minimum wage plus the payroll tax. The social security reform will result in a reduction of this tax. There are two sources for this reduction: first, as was the case in Chile, the reform itself may entail a reduction in the contribution. Second, the replacement of the old pay-as-you-go system by individual retirement accounts, reduces the disconnect between contributions and benefits. In the post reform period, at least part of the contribution will be considered as deferred compensation (see Section IV for an estimate for the case of Chile.)

Equations (1) - (4) describe the wage determination process in this economy. Equation (1) establishes that in equilibrium the wage rate in the informal sector $\left(\mathrm{W}_{\mathrm{I}}\right)$ is equal to the expected (net of taxes) wage rate in the modern sector $\mathrm{E}\left(\mathrm{W}^{\mathrm{N}}{ }_{\mathrm{M}}\right)$. According to equation (2) the probability of finding a job in the modern sector is equal to the ratio of openings - that is employment in that sector $\left(\mathrm{L}_{\mathrm{M}}\right)$ - to applicants. The latter is given by the sum of openings $\left(\mathrm{L}_{\mathrm{M}}\right)$ plus the total number of unemployed $(\mathrm{U})$. It is assumed, for 
simplicity, that the unemployed received an income equal to S. Equation (3) says that the cost of labor in the modern sector is equal to the minimum wage inclusive of the payroll $\operatorname{tax}\left(T_{1}\right)$. In equation (4) we present the demand for labor equations in the modern and informal sectors. $\mathrm{P}_{\mathrm{M}}$ and $\mathrm{P}_{\mathrm{I}}$ are good prices in each sector, the functions $\mathrm{f}(\mathrm{)}$ and $\mathrm{g}(\mathrm{)}$ are physical marginal productivity of labor. $\mathrm{K}_{\mathrm{M}}$ and $\mathrm{K}_{\mathrm{I}}$ are the stock of capital used in the modern and informal sector, respectively.

$$
\begin{aligned}
& \mathrm{W}_{\mathrm{I}}=\mathrm{E}\left(\mathrm{W}^{\left.\mathrm{N}_{\mathrm{M}}\right)}=\mathrm{p} \mathrm{W}_{\text {min }}+(1-\mathrm{p}) \mathrm{S}\right. \\
& \mathrm{p}=\left[\mathrm{L}_{\mathrm{M}} /\left(\mathrm{L}_{\mathrm{M}}+\mathrm{U}\right)\right] \\
& \mathrm{W}_{\mathrm{M}}=\mathrm{W}_{\min }\left(1+\mathrm{T}_{1}\right) \\
& \mathrm{W}_{\mathrm{M}}=\mathrm{P}_{\mathrm{M}} \mathrm{f}\left(\mathrm{L}_{\mathrm{M}}, \mathrm{K}_{\mathrm{M}}\right) ; \mathrm{W}_{\mathrm{I}}=\mathrm{P}_{\mathrm{I}} \mathrm{g}\left(\mathrm{L}_{\mathrm{I}}, \mathrm{K}_{\mathrm{I}}\right) .
\end{aligned}
$$

Equation (5) is the resource constraint in the labor market, and establishes that employment in the modern sector, plus employment in the informal sector plus unemployment has to be equal to total labor supply $\left(\mathrm{L}_{\mathrm{s}}\right)$. According to equation (6), labor supply is a positive function of real wages; O represents "other" factors affecting the supply of labor. ${ }^{23}$ Equation (7) define the aggregate price index and the aggregate wage rate, as geometric means of sectoral prices and wages, respectively. In order to simplify the analysis, in equation (8) we have assumed that the modern sector corresponds to tradable goods and that, as a consequence, $\mathrm{P}_{\mathrm{M}}$ is given by international prices $\left(\mathrm{P}^{*} \mathrm{M}\right){ }^{24}$ Equation (9) establishes that product prices in the informal sector are a positive function of wages in that sector. We further assume that an increase in $\mathrm{W}_{\mathrm{I}}$, will 
have a less than proportional effect on prices of goods produced in the informal sector. That is, $\mathrm{d} \log \mathrm{P}_{\mathrm{I}}<\mathrm{d} \log \mathrm{W}_{\mathrm{I}}$.

$$
\begin{aligned}
& \mathrm{L}_{\mathrm{M}}+\mathrm{L}_{\mathrm{I}}+\mathrm{U}=\mathrm{L}_{\mathrm{S}} \\
& \mathrm{L}_{\mathrm{S}}=\mathrm{h}(\mathrm{W} / \mathrm{P}, \mathrm{O}) ; \mathrm{h}^{\prime}>0 . \\
& \mathrm{P}=\mathrm{P}_{\mathrm{I}}{ }^{\beta} \mathrm{P}_{\mathrm{M}}{ }^{(1-\beta)} ; \mathrm{W}=\mathrm{W}_{\mathrm{I}}{ }^{\theta} \mathrm{W}_{\mathrm{M}}{ }^{(1-\theta)} \\
& \mathrm{P}_{\mathrm{M}}=\mathrm{P}^{*}{ }_{\mathrm{M}} ; \\
& \mathrm{P}_{\mathrm{I}}=\mathrm{z}\left(\mathrm{W}_{\mathrm{I}}\right) ; \mathrm{Z}^{\prime}>0 ; \mathrm{d} \log \mathrm{P}_{\mathrm{I}}<\mathrm{d} \log \mathrm{W}_{\mathrm{I}} .
\end{aligned}
$$

Equation (10) is the resource constraint for capital, and says that the sum of capital used in each sector has to equal the total stock of capital. Equation (11) says that the allocation of the capital stock across sectors will depend on the relative product prices. Notice that in order to simplify the computations, and to focus on the issues at hand, we have assumed that there is no net investment.

$$
\begin{aligned}
& \mathrm{K}_{\mathrm{M}}+\mathrm{K}_{\mathrm{I}}=\mathrm{K} \\
& \mathrm{K}_{\mathrm{M}}=\mathrm{j}\left(\mathrm{P}_{\mathrm{M}} / \mathrm{P}_{\mathrm{I}}\right) ; \mathrm{K}_{\mathrm{I}}=\mathrm{v}\left(\mathrm{P}_{\mathrm{M}} / \mathrm{P}_{\mathrm{I}}\right) .
\end{aligned}
$$

The initial (pre reform) labor market is depicted in Figure 1, under the simplifying assumption that the unemployed get no assistance $(\mathrm{S}=0)$. Distance $\mathrm{O}_{M}-\mathrm{O}_{\mathrm{I}}$ is total labor supply, $\mathrm{L}_{\mathrm{M}}$ and $\mathrm{L}_{\mathrm{I}}$ are the demand for labor schedules, and yy is a rectangular hyperbola, that satisfies the equilibrium condition in equation (1). The wage rate and the level of employment in the informal sector are determined by the intersection of the yy 
and $\mathrm{L}_{\mathrm{I}}$ schedules. $\mathrm{W}_{\min }$ is the minimum wage which, as stated above, is assumed to be set in net take-home bases. $\mathrm{T}_{1}$ is the payroll tax, and $\mathrm{W}_{\mathrm{M}}$ is the cost of labor in the modern sector. $\mathrm{W}_{\mathrm{I}}$ is the wage rate in the informal sector. The initial level of employment in the modern sector is given by distance $\mathrm{O}_{\mathrm{M}}-\mathrm{L}_{\mathrm{M}}{ }^{1}$; distance $\mathrm{O}_{\mathrm{I}}-\mathrm{L}_{\mathrm{I}}{ }^{1}$ depicts initial employment in the informal sector. The total number of unemployed is equal to distance $\mathrm{L}_{\mathrm{M}}{ }^{1}-\mathrm{L}_{\mathrm{I}}{ }^{1}$. As pointed out earlier, we consider the case where the reform reduces the (perceived) tax component of social security contributions. That is, we assume that as a result of the social security reform, there will be a reduction of $\mathrm{T}_{1}$, to some lower level, possibly even to zero. This would unleash a series of effects, including a higher demand for labor in the modern sector, a change in aggregate labor supply, and changes in wages and in employment in the informal sector.

Formally, the model given by equations (1) - (11) can be solved to obtain the effects of this type of social security reform, on a number of variables, including informal sector wages $\left(\mathrm{W}_{\mathrm{I}}\right)$, the volume of unemployment $(\mathrm{U})$, and product prices of in the informal sector $\left(\mathrm{P}_{\mathrm{I}}\right)$. In order to simplify the exposition, we follow a long tradition in international trade theory - the Ricardo-Viner approach - and we assume that capital is fixed in its sector of origin. We begin with the effects of changes in the tax component of the social security contribution $(\mathrm{d} \log \mathrm{T})$ on informal sector wages $\left(\mathrm{d} \log \mathrm{W}_{\mathrm{I}}\right)$ :

$$
\begin{aligned}
& \mathrm{d} \log \mathrm{W}_{\mathrm{I}}=\Delta^{-1}\left\{-\left[\alpha_{\mathrm{U}}\left(\mathrm{U} /\left(\mathrm{L}_{\mathrm{M}}+\mathrm{U}\right)\right)\left(1 / \eta_{\mathrm{M}}\right)\right]\right. \\
& -\left[\left(\mathrm{U} /\left(\mathrm{L}_{\mathrm{M}}+\mathrm{U}\right) \alpha_{\mathrm{M}}\left(1 / \eta_{\mathrm{M}}\right)\right]\right\}\left(\mathrm{T}_{1} /\left(1+\mathrm{T}_{1}\right)\right) \mathrm{d} \log \mathrm{T} .
\end{aligned}
$$

Where, 


$$
\begin{aligned}
\Delta=- & \alpha_{U}-\left[\alpha_{I}\left(U /\left(L_{M}+U\right)\right)\left(1 / \eta_{I}\right)(\mu-1)\right] \\
- & {\left[\left(U /\left(L_{M}+U\right)\right) \phi\left(\alpha_{I}+\mu \beta\right)\right] . }
\end{aligned}
$$

$\alpha_{I}, \alpha_{M}$ and $\alpha_{U}$ are the shares of employment in the informal sector, employment in the modern sector, and unemployment in the labor resources constraint (5). $\eta_{\mathrm{I}}$ and $\eta_{\mathrm{M}}$ are the inverse of the elasticities of the demand for labor with respect to wages in the I and M sectors, respectively, and are negative. ${ }^{25} \phi$ is the supply elasticity of labor, and is positive. $\mu$ is the elasticity of the price of informal sector goods $\left(\mathrm{P}_{\mathrm{I}}\right)$ with respect to the wage rate in that sector, and is greater than zero and smaller than one. It follows from equation (13), then, that $\Delta$ is negative. Consequently, according to equation (12), the following result holds:

$$
\left(\mathrm{d} \log \mathrm{W}_{\mathrm{I}} / \mathrm{d} \log \mathrm{T}\right)<0 .
$$

This means that a social security reform that reduces the payroll tax, will unambiguously generate an increase in the wage rate in the informal sector I, the sector that is not covered by the by the social security system, and that prior to the reform had the lowest wage rate. Notice that, by construction, net (take home) wages in the modern sector are not affected by the reform. This is because we have assumed that the minimum wage is set in take-home bases, and that the reform does not affect it. The more general case where the reform generates an increase in net wages in the $\mathrm{M}$ sector is discussed below. The effect of the reform on aggregate unemployment $(\mathrm{U})$, is given by: 
(14)

$$
\begin{aligned}
\mathrm{d} \log \mathrm{U}= & \Delta^{-1}\left\{\left(\alpha_{\mathrm{I}} / \eta_{\mathrm{I}}\right)-\left[\alpha_{\mathrm{I}}\left(\mathrm{U} /\left(\mathrm{L}_{\mathrm{M}}+\mathrm{U}\right)\right)\left(1 / \eta_{\mathrm{I}}\right)\left(1 / \eta_{\mathrm{M}}\right)(\mu-1)\right]\right. \\
& \left.-\left[\left(\mathrm{U} /\left(\mathrm{L}_{\mathrm{M}}+\mathrm{U}\right)\right) \phi\left(\alpha_{\mathrm{I}}+\mu \beta\right)\left(1 / \eta_{\mathrm{M}}\right)\right]\right\}\left(\mathrm{T}_{1} /\left(1+\mathrm{T}_{1}\right)\right) \mathrm{d} \log \mathrm{T} .
\end{aligned}
$$

The sign of equation (14) is undetermined. It follows from this that within the framework developed in this paper, a reduction in the payroll tax in the modern sector will have an ambiguous effect on the number of unemployed. Whether the level of unemployment will increase or decline will depend on two basic factors: the supply elasticity of labor in the economy -- parameter $\phi$ in equation (14) --; and the demand elasticity of labor demand in the informal sector. The more elastic is the supply for labor and the more inelastic is the demand for labor in the informal sector, the more likely it is that the reform will result in an increase in the level of unemployment.

Equation (15) gives the effect of the reform on product prices in the informal sector, and is positive:

$$
\begin{aligned}
\mathrm{d} \log \mathrm{P}_{\mathrm{I}}= & \Delta^{-1}\left\{-\left(\mathrm{U} /\left(\mathrm{L}_{\mathrm{M}}+\mathrm{U}\right)\right)\left(\alpha_{\mathrm{M}} / \eta_{\mathrm{M}}\right)\right. \\
& \left.-\alpha_{\mathrm{U}}\left(\mathrm{U} /\left(\mathrm{L}_{\mathrm{M}}+\mathrm{U}\right)\right)\left(1 / \eta_{\mathrm{M}}\right)\right\}\left(\mathrm{T}_{1} /\left(1+\mathrm{T}_{1}\right)\right) \mathrm{d} \log \mathrm{T} .
\end{aligned}
$$

The working of the model is illustrated in Figure 2, where it is assumed that the reform reduces the social security tax from $\mathrm{T}_{1}$ to $\mathrm{T}_{2}$. The new cost of labor in the modern sector is $\mathrm{W}_{\mathrm{M}}{ }^{2}$. Distance $\mathrm{O}_{\mathrm{I}}-\mathrm{O}_{\mathrm{I}}$ is assumed to be equal to the increase in the amount of labor supplied to the economy. Because of this increase in aggregate labor supply, the original demand for labor in the informal sector has to be redrawn as $\mathrm{L}_{\mathrm{I}}$. 
Since the product price of I has increased, the demand for labor in the informal sector shifts up, and is represented in Figure 2 by $\mathrm{L}_{\mathrm{I}}{ }^{\prime}\left(\mathrm{P}_{\mathrm{I}}{ }^{1}\right)$. The wage rate in the informal sector is now determined by the intersection of a new rectangular hyperbola y'y' and a new demand for labor in sector I, and is given by $\mathrm{W}_{\mathrm{I}}^{2}$. Employment in the informal sector has changed from distance $\mathrm{O}_{\mathrm{I}}-\mathrm{L}_{\mathrm{I}}{ }^{1}$ to distance $\mathrm{O}_{\mathrm{I}}{ }^{1}-\mathrm{L}_{\mathrm{I}}{ }^{2}$. Because of the reduction in $\mathrm{W}_{\mathrm{M}}$, employment in the modern sector has increased from $\mathrm{L}_{\mathrm{M}}{ }^{1}$ to $\mathrm{L}_{\mathrm{M}}{ }^{2}$. The new level of unemployment, which as indicated by equation (13), could be either higher or lower than the initial level of unemployment, is given by distance $\mathrm{L}_{\mathrm{M}}{ }^{2}-\mathrm{L}_{\mathrm{I}}^{2}$.

The results in equations (12) - (15) assume that there is no change in the takehome wage in the modern sector. In Chile, however, the government mandated an increase in take-home wages equal to 10 percent, for those that opted for the privatized regime (Edwards 1998a). In the context of the model developed in this paper, an increase in the take-home wage in the sector covered by social security can be modeled as an exogenously determined increase in the minimum wage rate. Formally speaking, then, this more general policy package corresponds to a situation where both the minimum wage $\left(\mathrm{W}_{\min }\right)$ and the payroll tax, change (in opposite directions). In this case the change in the wage rate in the informal sector will be given by:

$$
\begin{aligned}
\mathrm{d} \log \mathrm{W}_{\mathrm{I}}=\Delta^{-1} & \left\{\left[-\left[\alpha_{\mathrm{U}}\left(\mathrm{U} /\left(\mathrm{L}_{\mathrm{M}}+\mathrm{U}\right)\right)\left(1 / \eta_{\mathrm{M}}\right)\right]\right.\right. \\
- & {\left[\left(\mathrm{U} /\left(\mathrm{L}_{\mathrm{M}}+\mathrm{U}\right) \alpha_{\mathrm{M}}\left(1 / \eta_{\mathrm{M}}\right)\right]\right]\left\{\mathrm{T}_{1} /\left(1+\mathrm{T}_{1}\right)\right) \mathrm{d} \log \mathrm{T} } \\
& \left.+\mathrm{d} \log \mathrm{W}_{\min }\right\} .
\end{aligned}
$$

The change in the level of employment, in turn, will now be given by: 
(17)

$$
\begin{aligned}
\mathrm{d} \log \mathrm{U}= & \Delta^{-1}\left\{\left(\alpha_{\mathrm{I}} / \eta_{\mathrm{I}}\right)-\left[\alpha_{\mathrm{I}}\left(\mathrm{U} /\left(\mathrm{L}_{\mathrm{M}}+\mathrm{U}\right)\right)\left(1 / \eta_{\mathrm{I}}\right)\left(1 / \eta_{\mathrm{M}}\right)(\mu-1)\right]\right. \\
& \left.-\left[\left(\mathrm{U} /\left(\mathrm{L}_{\mathrm{M}}+\mathrm{U}\right)\right) \phi\left(\alpha_{\mathrm{I}}+\mu \beta\right)\left(1 / \eta_{\mathrm{M}}\right)\right]\right\}\left\{\left(\mathrm{T}_{1} /\left(1+\mathrm{T}_{1}\right)\right) \mathrm{d} \log \mathrm{T}\right. \\
& \left.+\mathrm{d} \log \mathrm{W}_{\min }\right\} .
\end{aligned}
$$

In this case, then, the final effect of the policy package will depend on the way in which the changes in the payroll tax and in the minimum wage are related to each other. A reasonable assumption - and one that captures the case of the Chilean reforms - is that the increase in the take-home wage in the modern sector, is equal to a fraction of the (percentage) reduction in the payroll taxes. Under these assumptions the qualitative results derived above for the more simple version of the model still apply: a social security reform that reduces the tax component of social security contributions will:

- increase the wage rate in the informal sector; which is the sector with the lowest wages under the pay-as-you-go system;

- will have an ambiguous effect on the level of unemployment.

Notice, however, that because the effect on unemployment is ambiguous, it is not possible to say anything definitive with respect to the effects of the reform on income distribution. In fact, it is possible that income becomes more unequally distributed as a result of the privatization of social security. ${ }^{26}$

Although the model developed here is simple, and has some limitations, it has enough structure to provide insights into some of the most important effects of a pension reform on labor markets. ${ }^{27}$ In Section IV we use micro survey data for 1994 to analyze 
some important characteristics of Chile's privatized social security system. In Section V we use the model developed here to simulate the effect of the social security reform on Chile's labor market outcomes.

\section{Chile's New Pension System: Who Is Covered? How Much Do Participants Value The System?}

The model developed in the preceding section can be used to analyze empirically the effect of social security reform on labor market outcomes. In order to calibrate and simulate the model, however, data on a number of key parameters are required. These include: (a) The rate of coverage of the social security system (parameter $\alpha_{M}$ ); (b) the wage elasticities of demand for labor, in the covered and uncovered sectors -- $\left(1 / \eta_{\mathrm{M}}\right)$ and $\left(1 / \eta_{I}\right)$. (c) The wage elasticity of supply of labor $(\phi)$; and (d), workers' perceptions of the tax component of social security contributions, under both the old pay-as-you-go regime, and the new privatized system.

In the case of Chile, some of these parameters (e.g. the labor elasticities) have been estimated in previous studies. Other key variables, however, are not readily available. In particular, there are no reliable calculations of the percentage of social security contributions that are considered to be a tax by labor market participants. In principle, this implicit tax can be obtained by estimating a wage rate equation that include a "compensating differential" for individuals that participate in the social security system. If social security contributions are considered to be a form of deferred compensation, individuals that are enrolled in the system would be willing to accept, for an equivalent job, a lower take-home (cash) wage than those individuals that do not participate in the 
social security system. If, however, social security contributions are considered to be fully a tax, those enrolled in the system will demand, for an equivalent job, the same cash salary than those that are not in the system and, thus, are not subject to this tax. The magnitude of the "compensating differential," for otherwise equivalent jobs will, then, provide an estimate of the proportion of the contribution that is actually perceived as a tax by labor market participants.

In this section we use micro data to estimate the implicit tax component of social security contributions. Ideally one would like to use comparable data for the pre and post reform era. Unfortunately, however, detailed survey data have only been collected since 1990. For this reason, we pursue the following strategy: First, we use micro data from the post-reform period to obtain a "base estimate" for the perceived tax component of the privatized social security system. Second, we make several alternative assumptions with respect to the perceived tax component of the old (pre-reform) system. This allows us to consider an interval of possible reductions of the tax stemming from the reform. Third, we combine this estimated range of tax reduction with parameters obtained from other studies to compute, using the model developed in Section III, the effects of Chile's social security's reform on the country's labor market.

Our basic data set is the CASEN (Caracterización Socioeconómica Nacional) national survey for 1994 . Using 1994 has a number of advantages. First, it is a fairly "normal" year, when Chile was neither facing a recession or serious disturbances from abroad. Second, it is a year when the democratic system was being consolidated, and thus the country was not subject to serious political disturbances. And third, in 1994 the privatized social security system had already been operational for some time, and was 
entering into a mature phase. The CASEN survey collects information on demographics, education, type of dwelling, health care, occupation, employment, and income, among other variables. We are interested on two specific, and interrelated, questions:

- What is the coverage of Chile's privatized social security system? Or, in other words, what percentage of those with a paying job, make contributions to the system? This is a key issue within the context of the model developed in Section III of this paper, where it was assumed that only a fraction of those in the labor market - those employed in the "formal" sector - participate in the social security system actively.

- To what extent do participants in the system consider it a deferred compensation scheme? As mentioned, we deal with this issue by estimating "compensating differential" wage equations. The results from these estimates are used as the bases for a simulation exercise presented in section $\mathrm{V}$.

\section{IV.1 Extent of Coverage of Chile's New Social Security System}

Table 1 presents summary data, for 1994, on the coverage of Chile's privately managed social security system. These data correspond to those individuals in the sample that had a paying job at the time of the survey, and have been organized by urbanrural sectors, age and gender. "AFP" refers to the percentage of individuals in that particular group that made contributions to a privately managed retirement fund (an AFP). "Other" refers to the percentage of individuals that made contributions to other retirement systems, including the old pay-as-you-go system and the armed forces retirement fund; "No" refers to those individuals that had not made contributions to any retirement system. 
The table is rather self-explanatory, and shows that as recently as 1994 Chile's system fell considerably short of universal coverage. Urban males have the highest coverage - defined as contributing to any retirement scheme --, at 69.9 percent. The lowest coverage corresponds to males in the rural sector, with $47.2 \%$. It may also be seen that, with the exception of rural males, those in the 16 to 39 year-old have the highest degree of coverage. For the sample as a whole, in 1994 the coverage rate of the formal retirement systems was $60.2 \%$. Data from the CASEN survey also suggest that there is a very high degree of compliance with respect to required contributions. More that $95 \%$ of employees with an employment contract made contributions, as required by law, to a retirement system.

Although there are no comparable survey data for the pre reform period, existing estimates indicates that Chile's old pay-as-you-go system covered $58 \%$ of those employed. This means, then, that after the privatization reform there has only been a small increase in the coverage of the formal retirement system. The fact that younger workers exhibit a higher coverage ratio may indicate, however, a secular trend towards greater participation in the system.

\section{IV.2 Deferred Compensation or Taxes?}

The model developed in section III of this paper assumes that a reform of the social security system implies a reduction in the (implicit) tax on labor. More specifically, we assume that while under the pay-as-you-go system, contributions are (largely) seen as taxes, under the privately managed regime contributions are seen (at least partially) as a deferred compensation scheme. In this subsection we use data from 
the CASEN survey to investigate whether, on average, individuals indeed value the new privatized system, and consider it as a component of their total compensation package.

For an individual employed in the formal sector, total labor compensation will be equal to his take-home (cash) salary, plus a proportion of his contribution to the retirement system. If contributions are fully seen as deferred compensation, that proportion will be equal to one. If on the other hand, contributions are fully seen as taxes, that proportion will be equal to zero, and the total compensation will be only equal to the take-home salary. ${ }^{28}$ In principle, then, the value attached by individuals to the pension system can be estimated by comparing wages from jobs that are equivalent in all respects, except with regard to contributions to the retirement program. If individuals value being enrolled in the pension's program, we would expect that, for otherwise equivalent jobs, the take-home pay of those that participate in the system will be lower than that of individuals that do not make contributions. The actual difference in the (cash) take-home pay, for otherwise equivalent jobs, can, then, be attributed to the value that individuals attach to being members of the retirement system.

We use survey data for over 23,000 individuals to estimate a "treatment" model, that combines a wage equation with an equation that captures the decision to contribute in the social security system: ${ }^{29}$

$$
\begin{aligned}
& \log \mathrm{w}_{\mathrm{j}}=\mathbf{x}_{\mathrm{j}} \beta+\gamma \mathrm{C}_{\mathrm{j}}+\mu_{\mathrm{j}} \\
& \mathrm{C}_{\mathrm{j}}=\left\{\begin{array}{l}
1, \text { if } \mathrm{C}^{*}{ }_{\mathrm{j}}>0 \\
0, \text { otherwise }
\end{array}\right.
\end{aligned}
$$




$$
\mathrm{C}^{*}{ }_{\mathrm{j}}=\mathbf{y}_{\mathbf{j}} \alpha+\varepsilon_{\mathrm{j}} \text {. }
$$

Equation (18) is the wage equation. $\log \mathrm{w}_{\mathrm{j}}$ is the $\log$ of take-home wages for individual $\mathrm{j} ; \mathbf{x}_{\mathbf{j}}$ is a vector of traditional determinants of real wages that include, among other, education, experience, size of firm, gender, and geographical location of the job; $\mathrm{C}_{\mathrm{j}}$ is an endogenous dummy variable (i.e. the treatment variable) that takes a value of one if individual $\mathrm{j}$ participates in the retirement system, and zero if he does not. $\mu_{\mathrm{j}}$ is an error term, whose properties are discussed below. $\beta$ and $\gamma$ are parameters to be estimated. The decision to contribute to the social security is assumed to be the result of an unobserved latent variable $\mathrm{C}^{*}{ }_{\mathrm{j}}$, described in equation $(20) . \mathrm{C}^{*}{ }_{\mathrm{j}}$, in turn, is assumed to depend linearly on vector $\mathbf{y}_{\mathbf{j}} \cdot \alpha$ is a parameters vector to be estimated, and $\varepsilon_{\mathrm{j}}$ is an error term. Error terms $\mu_{\mathrm{j}}$ and $\varepsilon_{\mathrm{j}}$ are assumed to be bivariate normal, with a zero mean and a covariance matrix given by:

$$
\left(\begin{array}{ll}
\sigma & \rho \\
\rho & 1
\end{array}\right)
$$

If the wage and contribution equations are independent, the covariance term $\rho$ in equation (21) will be zero.

Parameter $\gamma$ in equation (18) measures the (average) value that individuals attach to participating in the privatized social security system. We expect its estimated coefficient to be $\leq 0$. If the (average) value attached to social security contributions is zero - that is, if contributions are fully considered a tax --, the estimated coefficient 
should not be significantly different from zero. If, on the other hand, contributions are considered to be fully a deferred form of compensation, we would expect the estimated coefficient $\gamma$ to be approximately equal to the rate of contribution.

The model given by equations (18) - (20) can be estimated simultaneously using a maximum likelihood procedure. Chile's specific institutional arrangements, however, complicate somewhat the task of interpreting the results obtained from the estimation of this system. The main difficulty stems from the fact that the social security law requires individuals to make contributions not only to the retirement system (at 10\% of wages), but also to the health system (7\%) and to a mandated life insurance program (3\%). Total contributions for this "package," then, stand at $20 \%$ of wages. This means that the estimated value of parameter $\gamma$ is in the range of zero to $-20 \%$.

In the wage equation (18) the dependent variable is the log of net (take-home) wages; the notation used for the independent variables is provided in Table 3. We control for the usual variables that explain wage differentials, including schooling, experience (which, as customary, we proxy by age), experience squared, geographical location of the job, gender of the individual, and size of the firm where the individual is employed. The variable Contri is the endogenous dummy variable that indicates if the individual makes contributions to the system. In the estimation of equation (19) we assume that the decision on whether to make a contribution depends on schooling, age, industry where the individual is employed, size of the firm, gender, and whether the individual in question has a formal employment contract. Our data set consists of 23,198 civilian workers in the urban sector, that held a paying job, and did not receive retirement benefits at the time of the survey. Our sample excludes individuals with a household income 
below the indigent poverty line - or "extreme poverty line --, as well as those with a salary that exceed the maximum subject to social security contributions.

The results obtained from the joint estimation, using a maximum likelihood procedure, of the model given by equations (18) - (20) are presented in Table 2. The Wald test statistic for independence of the two equations (for the covariance term $\rho$ being equal to zero) is equal to 111 , strongly suggesting that both equations should indeed be estimated jointly. Panel A in table 2 corresponds to the wage equation (18), while Panel B contains the results for "treatment" equation (20). As may be seen from Table 2-A, the estimated coefficients for the traditional variables - schooling, experience and experienced squared - are along the line of what is expected, and are consistent with previous estimates for Chile and other emerging economies. Both schooling and experience have significant and positive coefficients; as expected, experience squared has a negative and significant coefficient. Women earn significantly less than men, and there are regional and firm size significant wage differentials. The most important result, for our purpose, is that the estimated coefficient of the social security contribution variable is significantly negative, as expected. Its point estimate -0.0885 suggests that, on average and for equivalent jobs, individuals that contribute to the social security (cum health) system have a take-home wage that is almost $9 \%$ lower than those that do not contribute to the system. Since the mandatory (for retirement and health) contribution is $20 \%$, this means that individuals that make contributions consider part of them as taxes. More specifically, these results suggest that individuals consider little over one half of their contribution to be a tax. 
A few words on the results from the treatment equation (Panel B in Table 2): the decision to contribute to the social security system is affected in a positive way by schooling, experience (although at a declining rate), and the size of the firm. Women tend to contribute less than men, and part time workers tend to contribute less than those that work full time. Naturally, and as expected, those that have an employment contract (dcontra) have a (very) high probability of contributing. Some of the sectoral variables are also significant, suggesting that with other things given, the probability of making contributions to the private social security system is affected by type of industry where the individual works.

In order to investigate for the robustness of the results reported in Table 2, we estimated earnings equations for alternative samples. The results obtained from these alternative estimations confirmed those reported in Table 2, and are not presented here due to space considerations. In section $\mathrm{V}$ of this paper we use the estimates reported in Table 2 as am input into our simulation exercises.

\section{Chile's Pension Reform and The Labor Market}

In this section we present the results from simulation exercises, based on the model derived in section III, on the effects of the social security reform on Chile's labor market. We proceed as follows: We use values for the key parameters from previous studies of the Chilean economy, as well as from the econometric results presented in the previous section to provide a "base case" calibration of the model. In order to test for the robustness of the results, we then consider alternative values for the key parameters. This 
procedure allows us to obtain a range of estimates for the effects of the social security reform on Chile's labor market variables.

In Table 4 we present the values of the parameters used in the simulation exercise. The elasticities were taken from previous studies on the Chilean economy. ${ }^{30}$ The data on the labor force and the rate of unemployment were taken from Banco Central de Chile. The percentage of workers in the informal sector was taken from the analysis reported in section IV of this paper. The parameter for $\mu$ was taken from a number of studies on Chile's inflation. In our base case analysis we assume that under the traditional pay-asyou-go system, contributions to the social security system (at an average rate of $26 \%$ of wages) were fully considered to be a tax; as pointed out above, benefits during the prereform era were considered to be an entitlement. Finally, we assumed that in the post reform period, mandated contributions to the pension system had a tax component equal to $5.6 \%$ of wages. That is, we assume that individuals considered that slightly over one half of the required contribution to the pension fund constituted a tax. This figure is based on the econometric results reported in the preceding section. More specifically, it was obtained by assuming that the perceived tax element of the contributions is equally distributed between the retirement component and the health component. ${ }^{31}$

In Table 5 we present the simulation results for the case where the reform reduces the (implicit) tax on labor, but where there is no increase in the take-home pay for those enrolled in the system. These results were obtained after calibrating equations (12) and (14) in Section III. Table 6, on the other hand, contains the results from a simulation exercise that assumes that the reform results in a $10 \%$ increase in net take-home pay for those enrolled in the system, and correspond to equations (16) and (17). In both tables 
we have presented a "low" and a "high" case scenario. As may be seen, these results suggest that, by reducing the implicit tax on labor, Chile's pension reform had a positive (but small) effect on wages in the informal sector, at the same time as it contributed to a reduction in the rate of unemployment.

The results in Table 6, which are based on assumptions that closely capture Chile's experience, suggest that the actual effect of the pension reform on labor market outcomes was rather modest with respect to unemployment reduction. According to our simulation exercise, in the high case scenario, the reforms only contributed 1.0 percentage points to the reduction of the rate of unemployment. The total effect on net wages was more important, however: first, according to this simulation exercise the reform contributed to an increase in net wages in the informal sector that ranged from 1.7 to 2.1 percent. Second, by design of the reform package net (take home) wages in the formal sector increased by $10 \%{ }^{32}$

An important question is how sensitive are these results to the assumption that labor market participants considered that under the old system the tax equivalent of contributions was $26 \%$ of wages, while under the privatized system it was $5.6 \%$ of wages. In order to deal with this issue we performed a series of simulation exercises, under alternative values of the perceived tax component of contributions, both before and after the reform. More specifically, we made the following alternative assumptions: (a) We assumed that under the old pay-as-you-go regime, half of the contribution was considered a $\operatorname{tax}\left(\mathrm{T}_{1}=13 \%\right)$. (b) With respect to the post-reform era, we considered a range of values for the tax component of contributions. These values go from an estimated tax $\left(\mathrm{T}_{2}\right)$ of $6.2 \%$ of wages, to $4.9 \%$ of wages. ${ }^{33}$ The results obtained under 
these alternative parameter values are close to those reported in Table 6. More specifically, this sensitivity analysis suggests the following lower bound for the estimated effects of Chile's social security reform: an increase in informal sector wages of $1.4 \%$, and a reduction in unemployment of 0.4 percentage points.

\section{Concluding Remarks}

In 1981, Chile reformed its social security system. An inefficient and insolvent pay-as-you-go regime was replaced by system based on individual retirement accounts. Over the years Chile's reform has been widely praised, and has been carefully studied by policy makers throughout the world. In this paper we have focused on a neglected aspect of Chile's social security reform: its impact on labor market outcomes, including unemployment and wages. We develop a model of the labor market where we assume that, as is the case in most emerging markets, a formal and an informal sectors coexist side by side. According to our model, a social security reform that reduces the implicit tax on labor in the formal sector - as was the case in Chile --, will result in an increase in the wage rate in the informal sector. The effect of this type of reform on aggregate unemployment is undetermined, however. Results from simulation exercises suggest that in the case of Chile the reforms resulted in a rather modest increase in informal sector wages: approximately $2 \%$. These results from the simulation exercise also suggest that the reforms made a positive, but modest, contribution to the reduction of Chile's aggregate of unemployment. 
Figure 1

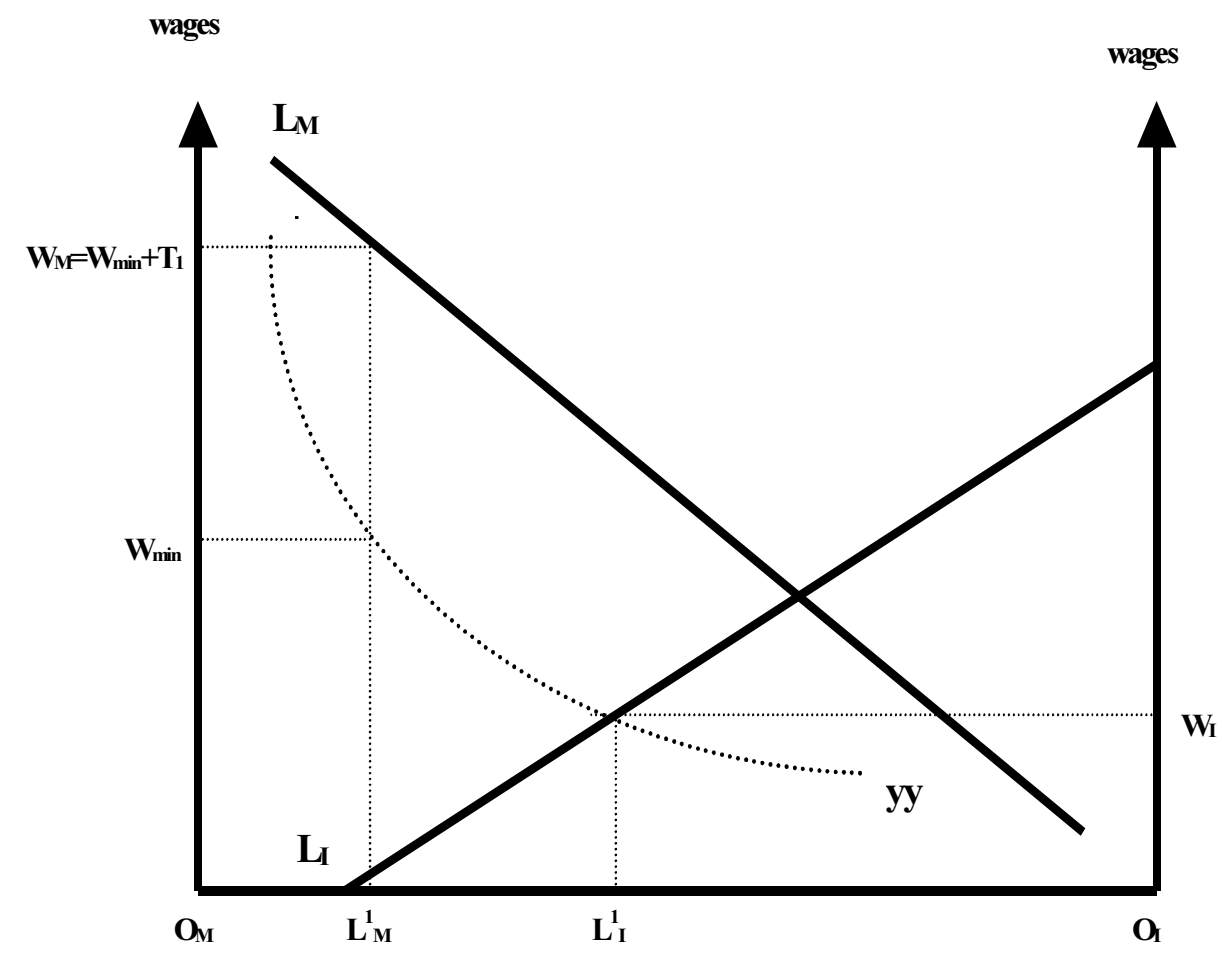


Figure 2

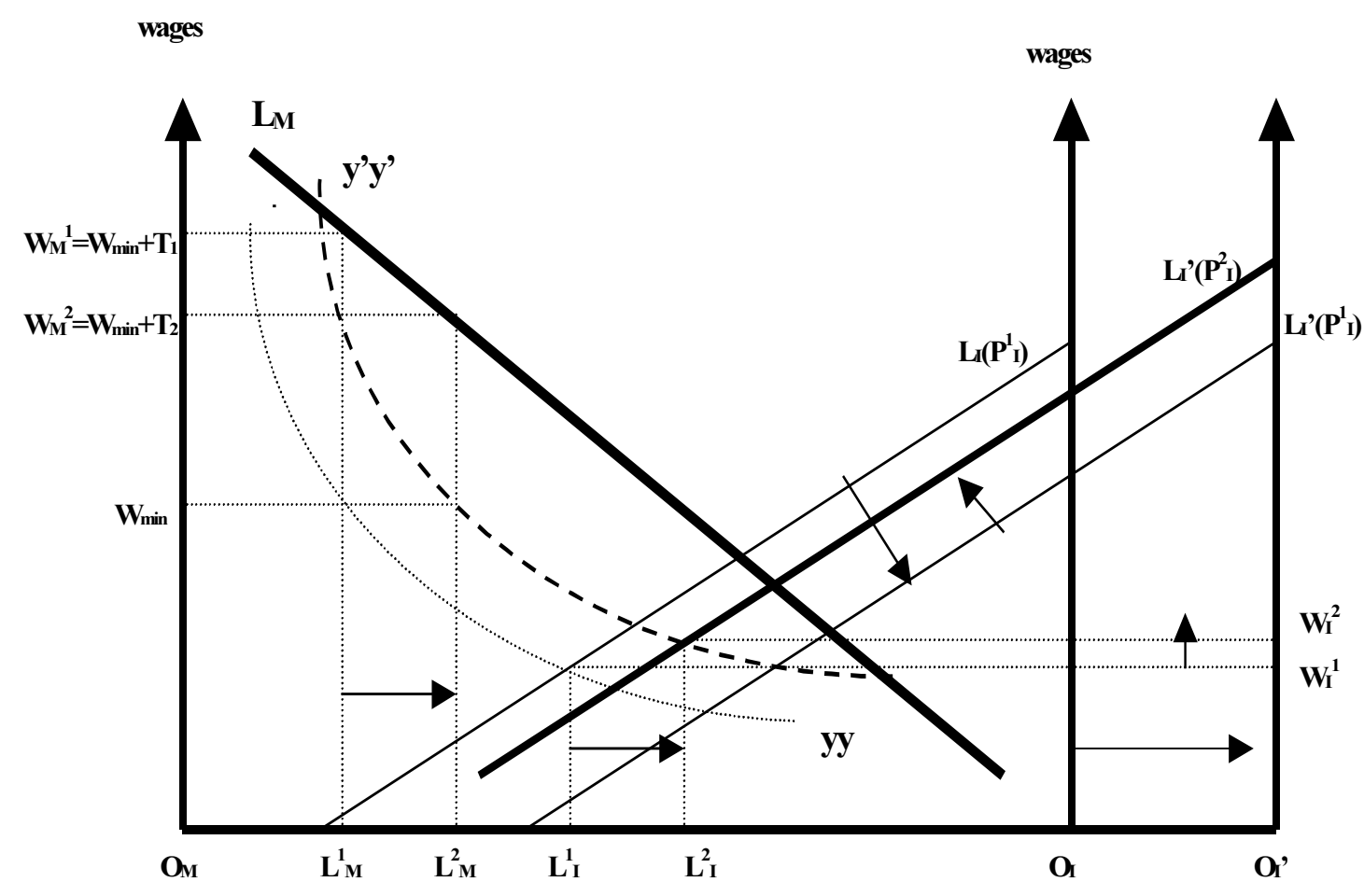


Table 1: Coverage of Chile's Social Security System, 1994:

Urban and rural, by age and gender*

A. URBAN

\begin{tabular}{|c|c|c|c|c|}
\hline & $\begin{array}{l}16 \text { to } 39 \\
\text { years }\end{array}$ & $\begin{array}{l}40 \text { to } 59 \\
\text { years }\end{array}$ & $\begin{array}{l}60 \text { plus } \\
\text { years }\end{array}$ & Total \\
\hline \multicolumn{5}{|l|}{ URBAN } \\
\hline \multicolumn{5}{|l|}{ Males } \\
\hline AFP & 68.87 & 60.01 & 35.02 & 63.36 \\
\hline Other & 3.09 & 9.84 & 18.95 & 6.58 \\
\hline No & 28 & 30.15 & 46.04 & 30.03 \\
\hline no answer & 0.04 & 0 & 0 & 0.02 \\
\hline Total & 100 & 100 & 100 & 100 \\
\hline \multicolumn{5}{|l|}{ URBAN } \\
\hline \multicolumn{5}{|l|}{ Females } \\
\hline AFP & 66.56 & 52.89 & 24.57 & 59.63 \\
\hline Other & 2.46 & 9.27 & 16.72 & 5.57 \\
\hline No & 30.98 & 37.6 & 58.71 & 34.72 \\
\hline no answer & 0 & 0.24 & 0 & 0.08 \\
\hline Total & 100 & 100 & 100 & 100 \\
\hline
\end{tabular}




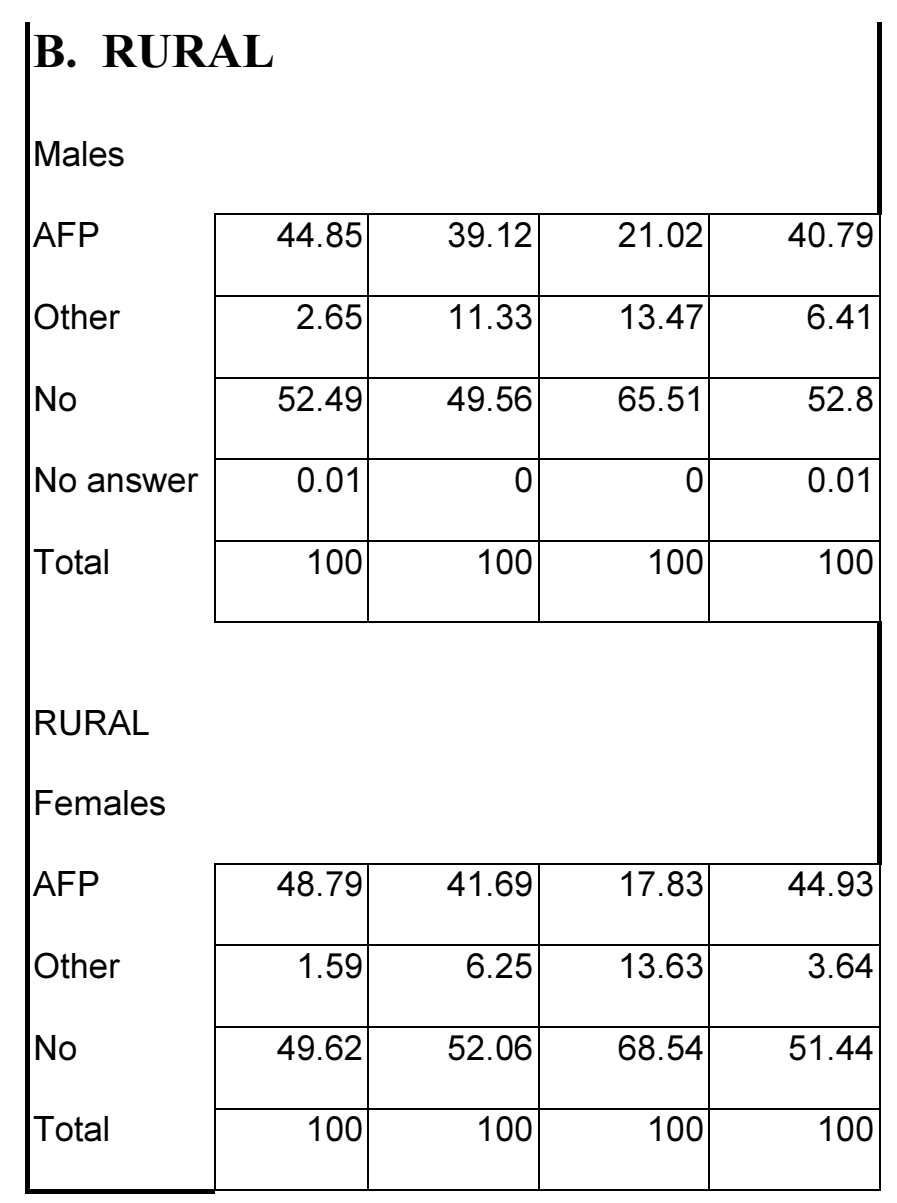

* Totals may no add up to 100 due to rounding errors.

Source: calculated by the authors using raw data from Casen 94 


\section{TABLE 2}

Wages and Social Security Contributions

(Maximum Likelihood Simultaneous Estimation)

\section{A. Wage Equation}

(Dependent variable: log of take-home (net) wages)

\begin{tabular}{|c|c|c|c|c|}
\hline & \multicolumn{3}{|c|}{ Robust } & \multirow[b]{2}{*}{$P>|z|$} \\
\hline & Coef. & Std. Err. & $\mathrm{z}$ & \\
\hline----------- & ----------- & ---------- & ------ & ------ \\
\hline yschool & .079173 & .0010154 & 77.97 & 0.000 \\
\hline ex & .0217501 & .0007858 & 27.68 & 0.000 \\
\hline ex2 & -.0001781 & .0000159 & -11.20 & 0.000 \\
\hline woman & -.1636414 & .0066837 & -24.48 & 0.000 \\
\hline REGION1 & .0479687 & .0116115 & 4.13 & 0.000 \\
\hline REGION2 & -.0120154 & .0125271 & -0.96 & 0.337 \\
\hline REGION3 & -.0427694 & .0129711 & -3.30 & 0.001 \\
\hline FIRM6_9 & .0166319 & .0132469 & 1.26 & 0.209 \\
\hline FIRMI0_49 & .0554989 & .0089351 & 6.21 & 0.000 \\
\hline FIRM50_199 & .1193046 & .0105452 & 11.31 & 0.000 \\
\hline FIRM_200 & .2371546 & .0107323 & 22.10 & 0.000 \\
\hline Contri & -.0885305 & .0129523 & -6.84 & 0.000 \\
\hline _cons & 10.45468 & .019303 & 541.61 & 0.000 \\
\hline
\end{tabular}

\section{B. Treatment Equation}

(Dependent variable: Dummy for social security contributions)

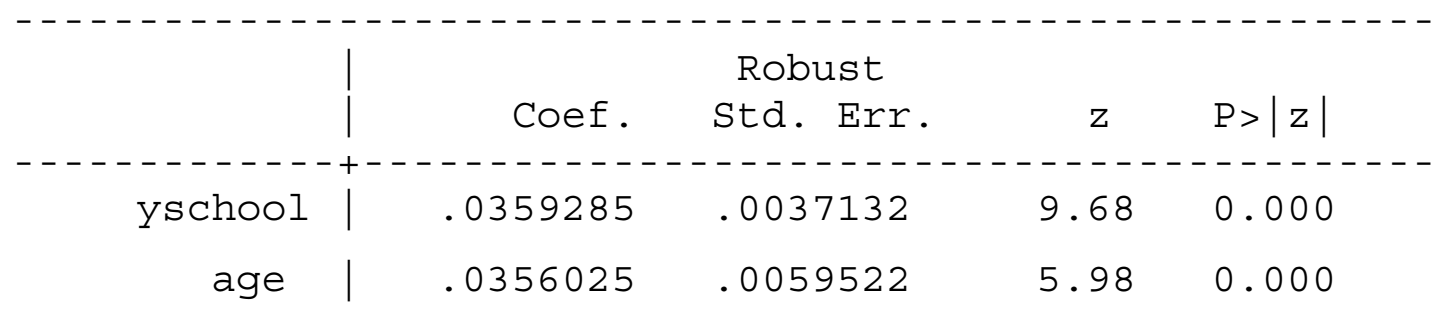




\section{(Table 2, continuation)}

\begin{tabular}{|c|c|c|c|c|}
\hline age2 & -.0003571 & .0000723 & -4.94 & 0.000 \\
\hline FIRM6_9 & .0849724 & .0483861 & 1.76 & 0.079 \\
\hline FIRM10_49 & .3225233 & .0344014 & 9.38 & 0.000 \\
\hline FIRM50_199 & .4179108 & .0455909 & 9.17 & 0.000 \\
\hline FIRM_200| & .5256829 & .0514504 & 10.22 & 0.000 \\
\hline part_ti & -.2436089 & .0600502 & -4.06 & 0.000 \\
\hline woman & -.1087624 & .0288949 & -3.76 & 0.000 \\
\hline AGRI & .2301454 & .1331833 & 1.73 & 0.084 \\
\hline MINI & .286353 & .1472251 & 1.95 & 0.052 \\
\hline INDU & .2978188 & .1297052 & 2.30 & 0.022 \\
\hline UTIL & .2220377 & .1905074 & 1.17 & 0.244 \\
\hline CONS & .2163195 & .1317592 & 1.64 & 0.101 \\
\hline COMM & .2355087 & .128338 & 1.84 & 0.066 \\
\hline TRAN & .1413476 & .1317512 & 1.07 & 0.283 \\
\hline FINA & .4103262 & .139452 & 2.94 & 0.003 \\
\hline GOV & .2871577 & .1284112 & 2.24 & 0.025 \\
\hline dcontract & 1.93364 & .0283869 & 68.12 & 0.000 \\
\hline _cons & -1.841414 & .1741268 & -10.58 & 0.000 \\
\hline \multicolumn{5}{|c|}{ 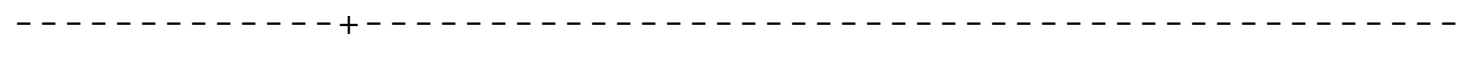 } \\
\hline \multicolumn{5}{|c|}{ 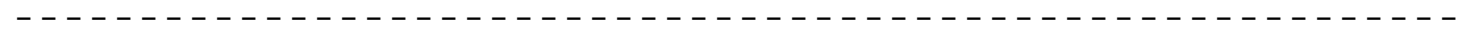 } \\
\hline Number of obs & \multicolumn{2}{|c|}{$=\quad 23198$} & & \\
\hline Wald chi2 (12) & \multicolumn{2}{|c|}{7967.36} & & \\
\hline Prob > chi2 & \multicolumn{2}{|c|}{0.0000} & & \\
\hline Log likelihood & $=-2151$ & 074 & & \\
\hline
\end{tabular}

Wald test of indep. eqns.

$($ rho $=0): \operatorname{chi2}(1)=110.95$;

Prob $>$ chi2 $=0.0000$ 
Table 3: Notation Used in Estimation of Treatment Model

\begin{tabular}{|c|c|}
\hline yschool & Years of schooling \\
\hline ex (age) & Experience measured by age \\
\hline $\exp 2$ (age2) & Experience (age) squared \\
\hline AGRI & Dummy for agriculture \\
\hline MINI & Mining \\
\hline INDU & Industry \\
\hline UTIL & Utilities \\
\hline CONS & Construction \\
\hline COMM & Commerce \\
\hline TRAN & Transportation \\
\hline FINA & Financial services \\
\hline GOV & Government \\
\hline REGi & $\begin{array}{l}\text { Regional dummies }(\mathrm{i}=1 . .3) \text {. REG1 refers to the two largest } \\
\text { metropolitan areas. }\end{array}$ \\
\hline Contri & $\begin{array}{l}\text { Dummy that takes value of one if the individula has made a } \\
\text { contribution to the socila security system }\end{array}$ \\
\hline FIRMj_k & $\begin{array}{l}\text { Dummy that takes value of one if the firm where the } \\
\text { individual is employed has } j \text { to k workers. FIRM_200 refers } \\
\text { to firms with } 200 \text { or more workers. }\end{array}$ \\
\hline
\end{tabular}




\begin{tabular}{|c|l|}
\hline Part ti & Dummy that takes value of one if individual works part time \\
\hline dcontract & $\begin{array}{l}\text { Dummy that takes the value of one if the individual has an } \\
\text { employment contract }\end{array}$ \\
\hline Woman & Dummy that takes a value of one if the individual is a woman \\
\hline & \\
\hline
\end{tabular}


Table 4: Parameter Values Used in Simulation Exercises

\begin{tabular}{|l|l|l|}
\hline PARAMETER & DESCRIPTIPON & VALUE \\
\hline $\mathrm{F}$ & Total labor force (thousand of people) & 3,700 \\
\hline $\mathrm{L}_{\mathrm{M}}$ & Employment in modern sector (thousands) & 1,850 \\
\hline $\mathrm{L}_{\mathrm{I}}$ & Employment in "informal" sector (thousands) & 1,450 \\
\hline $\mathrm{U}$ & Unemployed (thousands) & 400 \\
\hline$\mu$ & $\begin{array}{l}\text { Wage "passover coefficient" in prices in } \\
\text { Informal sector goods }\end{array}$ & 0.3 to 0.5 \\
\hline$\phi$ & $\begin{array}{l}\text { Supply elasticity of labor with respect to } \\
\text { wages }\end{array}$ & 0.3 \\
\hline$\beta$ & Weight of informal sector prices in price level & 0.3 \\
\hline$\left(1 / \eta_{\mathrm{I}}\right)$ & Post reform implicit tax on labor & $5.6 \%$ \\
\hline$\left(1 / \eta_{\mathrm{M}}\right)$ & $\begin{array}{l}\text { Demand elasticity for labor in informal sector } \\
\mathrm{T}_{2}\end{array}$ & -0.5 to -0.7 \\
\hline $\mathrm{T}_{1}$ & \begin{tabular}{l} 
Demand elasticity for labor in modern sector \\
\hline
\end{tabular} & -0.4 to -0.6 \\
\hline
\end{tabular}

Source: see text. 
TABLE 5:

Chile's Pension Reform and the Labor Market:

Simulation Results ${ }^{\text {a }}$

(Equations 12 and 14)

\begin{tabular}{|l|c|c|}
\hline & Low Case Scenario & High Case Scenario \\
\hline $\begin{array}{l}\text { Percentage change in real } \\
\text { wage in informal sector }\end{array}$ & $3.8 \%$ & $4.8 \%$ \\
\hline $\begin{array}{l}\text { Change in rate of } \\
\text { unemployment (in } \\
\text { percentage points) }\end{array}$ & $-1.5 \%$ & $-2.1 \%$ \\
\hline
\end{tabular}

a: This exercise assumes that there is no change in the net take-home pay for those in the "formal" segment of the labor market.

Source: Calculated by the authors on the bases of the model developed in section III of this paper. 
TABLE 6:

Chile's Pension Reform and the Labor Market:

Simulation Results ${ }^{\text {a }}$

(Equations 16 and 17)

\begin{tabular}{|l|c|c|}
\hline & Low Case Scenario & High Case Scenario \\
\hline $\begin{array}{l}\text { Percentage change in real } \\
\text { wage in informal sector }\end{array}$ & $1.7 \%$ & $2.1 \%$ \\
\hline $\begin{array}{l}\text { Change in rate of } \\
\text { unemployment (in } \\
\text { percentage points) }\end{array}$ & $-0.7 \%$ & $-1.0 \%$ \\
\hline
\end{tabular}

a: This exercise assumes that, at the time of the reform, there is a $10 \%$ increase in the net take-home pay for those in the "formal" segment of the labor market.

Source: Calculated by the authors on the bases of the model developed in section III of this paper. 


\section{ENDNOTES}

${ }^{1}$ World Bank, 1994. The Old Age Crisis, Washington, D.C. On Chile's reforms, see Edwards, Sebastian, and Alejandra Edwards. 1991. Monetarism and Liberalization: The Chilean Experiment. Chicago: University of Chicago Press, second edition, and Bosworth, Barry P.; Dornbusch, Rudiger, and Raúl Labán, editors. 1994. The Chilean Economy: Policy Lessons and Challenges. Washington, DC: The Brookings Institution. 2 See, for example, the discussion in Diamond, Peter and Salvador Valdés-Prieto. 1994. [Social Security Reforms.] In The Chilean Economy: Policy Lessons and Challenges, edited by B. Bosworth, R. Dornbusch and R. Labán. Washington, DC: The Brookings Institution.

3 The papers collected in Gruber J. and D. A. Wise, (Eds) 1999. Social Security and Retirement around the World, University of Chicago Press, analyze in great detail the way in social security affects labor force decisions of older persons in eleven industrialized countries.

${ }^{4}$ Siebert, Horst. 1998. "Pay-as-you-go versus capital funded Pension systems. The Issues" in Redesigning Social Security, H. Siebert (Ed.), Kiel Institute of the World Economy., Lorz, Oliver. 1998. "Social Security and Employment", in Redesigning Social Security, H. Siebert (Ed.), Kiel Institute of the World Economy, and Edwards, Sebastian, 1998b. "Chile: Radical Change Towards a Funded System” in Redesigning Social Security, H. Siebert (Ed.), constitute some of the few papers that analyze the possible effects of social security reforms on labor markets. 
${ }^{5}$ This is equivalent to analyzing whether, as expected by the architects of the reforms, individual participants consider contributions into the new system as deferred compensation.

${ }^{6}$ The decision to replace the government-run program by one based on privately managed individual retirement accounts was part of an ambitious program aimed at transforming Chile into a market-oriented economy.

7 See Diamond, Peter. 1994. DPrivatization of Social Security: Lessons from Chile.] Revista de Análisis Económico 9 (1) (June): 21-34.

${ }^{8}$ Cox-Edwards, Alejandra. 1992. "Economic Reform and Labor Market Legislation in Latin America." California State University, mimeo and Diamond and Valdes-Prieto. 9 There are no penalties for working while receiving a pension.

10 In case an accumulated fund does not provide for an annuity above the minimum pension, the state complements the funds, so long as the individual has made contributions for a minimum of twenty years.

${ }^{11}$ Iglesias, A. and D. Vittas, 1992. TThe Rationale and Performance of Personal Pension Plans in Chile], Working Paper 867, The World Bank.

12 Fuentes Silva, Roberto. 1995. DEvolución y resultados del sistema.C In Quince años despues: Una mirada al sistema privado de pensiones, edited by S. Baeza and F. Margozzini. Santiago: Centro de Estudios Públicos.

${ }^{13}$ Baeza Valdés, Sergio, and Raúl Burger Torres. 1995. [Calidad de las pensiones del sistema privado chileno. In Quince años despues: Una mirada al sistema privado de pensiones, edited by S. Baeza and F. Margozzini. Santiago: Centro de Estudios Públicos. 
${ }^{14}$ On industrial countries replacement rates see, for example, Davis, E. P.1998. "'Pensions in the Corporate Sector", in Redesigning Social Security, H. Siebert (Ed.), and the papers in Grueber and Wise. Naturally, since this is a defined contribution system, future replacement rates may vary.

${ }^{15}$ See Edwards, Sebastian, 1998a. " The Chilean Pension Reform: A Pioneering Program", in Privatizing Social Security, by M. Feldsrein (ed.). for details on the system's operative aspects and Cox-Edwards, Alejandra. 2000. "Pension projections for Chilean Men and Women: Estimates from social security contributions" (The World Bank), .for the impact of the reform on women's income.

16 This point has been forcefully made by Diamond and Valdes-Prieto, among others.

17 See Edwards, Sebastian, and Alejandra Edwards. 2000. "Economic Reforms and Labor Market: Policy Issues and Lessons from Chile". Economic Policy, April 2000, for details on the labor reforms.

${ }^{18}$ Strictly speaking this improved performance began in 1985-86, after Chile recovered from the debt crisis.

${ }^{19}$ The initial level of wages was, however, highly depressed Edwards and Edwards, Monetraism.

${ }^{20}$ Bach,M. and Ricardo Paredes (1996) “Are There Dual Labor Markets in Chile?: Empirical Evidence", Journal-of-Development-Economics; 50(2), August 1996, pages 297-312., present micro-based evidence for Chile that supports the view that the country's labor market is characterized by the coexistence of these two labor segments. 21 Diamond and Valdes-Prieto. In the case of Chile, Torche, A. And Gert Wagner, 1997. "Prevision Social: Valoracion Individual de un Beneficio Mandatado". 
de Economia, N 103, pp. 363-390, have argued that, although the reform reduced the tax component of contributions to social security, it did not fully eliminated it. In section III of this paper we use micro survey data to investigate this issue in detail.

22 This mechanism is similar to the one consider in migration models of the HarrisTodaro type. In our model, however, there is no migration. The assumption of risk neutrality is not essential; all the results will follow if individuals have a constant degree of risk aversion.

23 We have abstracted from intertemporal issues. Altough our results will still go through in an explicit intertemporal context, the computations would become significantly more complex.

24 This simplification allows us to maintain product prices in the modern sector constant. An alternative assumption, and one that would not affect the basic aspect of the analysis, is that the modern sector is comprised of both tradable and non-tradable goods. In this case, we would need a product market clearing condition for modern sector goods.

25 That is, $\eta_{\mathrm{I}}=\left(\mathrm{d} \log \mathrm{W}_{\mathrm{I}}\right) /\left(\mathrm{d} \log \mathrm{L}_{\mathrm{I}}\right)$.

26 There is some evidence that, in spite of poverty reduction, income distribution became more unequal in Chile during the 1980's and 1990s. See Valdes, A. 1999. "Poverty and income Distribution in a High Growth Economy: Chile, 1987-95" in G. Perry and D. M. Leipziger (Eds) Chile: Recent policy Lessons and Emerging Challenges, The World Bank, for an analysis of the evolution of poverty and income distribution in Chile in the 1980-1994 period.

27 Some of the limitations of the model include the fact that it does not consider all the channels through which the reform will feedback to the rest of the economy. Also, it 
does not consider explicitly the (possible) effect on the labor supply of the elimination of the expected future benefits of the entitlement component of the old system. This effect, however, is likely to be small and could be easily incorporated into the system by amending equation (6).

28 This, however, is only a first order approximation. The actual proportion of the contribution will depend on the individual's rate of discount, and the pension fund's rate of return, among other things.

${ }^{29}$ Maddala, G.S. 1983. Limited Dependent and Qualitative Variables in Econometrics, Cambridge University Press, Cambidge, U.K.

${ }^{30}$ Coeymans J.E. 1992 "Productividad, Salarios y Empleo en la Economía Chilena," Cuadernos de Economía, August, 1992, and Coeymans J.E. and Y. Mundlak, 1993. "Sectoral growth in Chile: 1962-82", Research Report, vol. 95. Washington, D.C.: International Food Policy Research Institute.

31 The results in Table 2 suggest that, after controlling for other factors, those individuals that are subject to mandated contributions (at a $20 \%$ rate), have a take-home pay that is on average $8.9 \%$ below that of individuals that don't participate in the system. The estimated perceived tax of the pension component is, then, calculated as [0.1-(0.089 /2) $]=0.056$.

32 We also simulated the model under the assumption that the supply for labor is inelastic. In this case the estimated increase in informal sector salaries is higher, ranging from $3.7 \%$ to $6.2 \%$.

33 These bounds are derived from the point estimate, plus/minus one standard deviation. 